ISSN 1818-1295 elSSN 2616-6194

REPORTS OF MORPHOLOGY
$\begin{gathered}\text { Official Journal of the Scientific Society of Anatomists, } \\ \text { Histologists, Embryologists and Topographic Anatomists } \\ \text { of Ukraine } \\ \text { journal homepage: https://morphology-journal.com }\end{gathered}$

\title{
Sex-age features of the prevalence and structure of heart rhythm disorders in the patients with severe Covid-infection
}

Mostovoy Y.M., Danilevych T.D.

National Pirogov Memorial Medical University, Vinnytsya, Ukraine

\section{ARTICLE INFO}

Received: 10 December, 2020

Accepted: 15 January, 2021

UDC: $616.98: 616.12-008.318-053.8$

\section{CORRESPONDING AUTHOR}

e-mail: danilevychtd@gmail.com Danilevych T.D.
There is growing evidence that arrhythmias are a major complication of COVID-19 infection. Inflammation of the myocardium, cytokine storm, hypoxia, changes of electrolyte levels, coronary vasospasm, microcloths may be factors that contribute to the development of arrhythmias and changes of the ECG. The aim of the study was to determine the sex and age characteristics of the prevalence and structure of cardiac arrhythmias in patients with severe COVID infection. In the study were examined 133 patients with severe COVID-19 infection, who were in the intensive care unit of the city clinical hospital №1 in Vinnytsia at the period from April to December 2020 and as a result of treatment with improved health were discharged from the hospital. Statistical processing of the obtained data was performed using the statistical software package SPSS 12.0 for Windows using parametric and non-parametric methods of statistical analysis. It was found that the most common comorbid pathologies of the patients with severe COVID-19 were - arterial hypertension 90 (67.7\%), coronary heart disease 91 (68.4\%), chronic heart failure 65 (48.9\%), obesity 47 (35.3\%) and diabetes mellitus 32 (24.1\%). It was found that the prevalence of cardiac arrhythmias in patients with severe COVID-19 was $86(64.7 \%)$ patients. Among all arrhythmias, tachyarrhythmias predominated - $68(51.1 \%)$, in the structure of which sinus tachycardia was the most common in 45 (33.8\%) and atrial fibrillation (AF) - in 19 (14.3\%) patients, respectively. In turn, sinus tachycardia was significantly more common among women. The prevalence of bradyarrhythmias was 60 (45.1\%), in the structure of which were dominated sinus bradycardia $16(12 \%)$ and blockade of the right branch of the His bundle $30(22.6 \%)$. Among men, there was a tendency to the predominance of complete left bundle branch block. The prevalence of ischemic changes and/or repolarization disorders according to the ECG was 119 (89.5\%), in the structure of which were dominated the presence of inversion of the T wave 91 (68.4\%) and depression of the ST segment 54 (40.6\%). The mean age of the patients with ischemic ECG changes was significantly higher compared to patients without signs of repolarization disorders. Among men, there was a predominance of pancreatic hypertrophy and a tendency to predominance of left ventricular hypertrophy.

Keywords: COVID, heart rhythm disorders, arrhythmia, atrial fibrillation, premature beat, heart block, arterial hypertension, coronary heart disease, chronic heart failure.

\section{Introduction}

The experience we gained during the epidemic of COVID-19 infection showed that a significant proportion of patients have various cardiovascular complications. Namely, myocarditis, heart failure and acute coronary syndrome resulting from coronary artery thrombosis or rupture of atherosclerotic plaques as a complication of COVID infection.

There is growing evidence that arrhythmias are also a major complication. Inflammation of the myocardium caused by a viral infection leads to electrophysiological and structural remodeling as a possible mechanism of arrhythmias [4]. Also, hypoxia and electrolyte changes during the acute phase of COVID infection have often been reported in patients with severe disease, which are known to contribute to the development of acute arrhythmias [20].

A recent study reported that about $7 \%$ of patients with COVID infection complain of palpitations [22]. According to a report by Chinese researchers D. Wang and co-authors 
(2020), cardiac arrhythmias were reported in $16.7 \%$ of hospitalized and $44.4 \%$ of patients in the COVID-19 intensive care unit [29]. In the analysis of 115 patients $(69$ of them hospitalized in the intensive care unit and 46 patients in other departments), it was found that paroxysms of supraventricular tachyarrhythmias, namely atrial fibrillation (AF), flutter and atrial tachycardia (PT), were observed in 19 patients (16.5\%) among all hospitalized and all of them were in the intensive care unit $(27.5 \%)$ [10].

According to a survey of 1,100 electrophysiologists from 76 countries, AF was the most common tachyarrhythmia, and sinus bradycardia and complete atrioventricular block were the most common bradyarrhythmias in patients with COVID-19 infection [13]. The mechanisms that can cause $A F$ in these patients may be due to systemic infection, direct viral cardiomyocyte involvement, hypoxemia and susceptibility due to old age, comorbidities, and overactive sympathetic nervous system [27].

Another study found that among 187 hospitalized patients, $13(7 \%)$ had ventricular tachyarrhythmias during hospitalization. In addition, malignant arrhythmias, including ventricular tachycardia/ventricular fibrillation, were more common in patients with elevated T-troponin levels [14]. Ventricular arrhythmias and torsade de pointes have also been reported due to QT prolonging drugs, especially azithromycin and hydroxychloroquine [9].

Therefore, the exact effect of COVID-19 infection on the development of arrhythmias in asymptomatic, mildly ill, critically ill and recovered patients is unknown [20]. There are currently no studies aimed directly at studying arrhythmias in patients with COVID-19. Of particular interest to us, both from a practical and scientific point of view, is the study of the prevalence and features of cardiac arrhythmias among patients with COVID-19 infection among the population of Ukraine.

The aim of the study was to establish the sex and age characteristics of the prevalence and structure of cardiac arrhythmias in patients with severe COVID infection.

\section{Materials and methods}

133 patients who were in the intensive care unit of the city clinical hospital №1 Vinnytsia in the period from April to December 2020 were examined and were discharged from the hospital with improved health.

Among them there were 65 (48.9\%) men and 68 (51.1\%) women $\left(x^{2}=0.068, p=0.79\right)$. The age of patients ranged from 24 to 90 years, averaging $61.38 \pm 12.96$ years. Age gradation showed that the group under the age of 45 included 13 $(9.8 \%)$ patients, $45-59$ years $-46(34.6 \%), 60-74$ years -56 (42.1\%), 75-90 years - $18(13.5 \%)$ patients. The age structure was dominated by middle-aged and elderly patients $(p=0.001)$.

The total length of stay in hospital was $18.90 \pm 9.12$ days. The length of stay in the intensive care unit varied from 1 to 37 days and averaged $8.320 \pm 6.919$ days.

The polymerase chain reaction was performed in all
Table 1. The structure of comorbidity in patients with severe COVID-infection.

\begin{tabular}{|l|c|}
\hline \multicolumn{1}{|c|}{ Comorbidity } & $\begin{array}{c}\text { Proportion of } \\
\text { patients }(\mathrm{n}=133)\end{array}$ \\
\hline Hypertension $(\mathrm{n}=90)$ & $67.7 \%$ \\
\hline IHD $(\mathrm{n}=91)$ & $68.4 \%$ \\
\hline CHF $(\mathrm{n}=113)$ & $85.0 \%$ \\
\hline Combination of Hypertension and IHD $(\mathrm{n}=79)$ & $59.4 \%$ \\
\hline DM $(\mathrm{n}=32)$ & $24.1 \%$ \\
\hline Coronary artery bypass grafting $(\mathrm{n}=2)$ & $1.5 \%$ \\
\hline Prosthetics of valves $(\mathrm{n}=2)$ & $1.5 \%$ \\
\hline Rheumatic heart disease $(\mathrm{n}=1)$ & $0.8 \%$ \\
\hline Kidney disease $(\mathrm{n}=13)$ & $9.8 \%$ \\
\hline Cancer ( $\mathrm{n}=8)$ & $6.0 \%$ \\
\hline Gastrointestinal diseases $(\mathrm{n}=17)$ & $12.8 \%$ \\
\hline COPD/Asthma $(\mathrm{n}=9)$ & $6.8 \%$ \\
\hline $\begin{array}{l}\text { Acute cerebrovascular accident in the anamnesis } \\
(\mathrm{n}=11)\end{array}$ & $8.3 \%$ \\
\hline Thyroid disease $(\mathrm{n}=9)$ & $6.8 \%$ \\
\hline Multiple sclerosis $(\mathrm{n}=1)$ & $0.8 \%$ \\
\hline Anxiety and depressive disorder $(\mathrm{n}=1)$ & $0.8 \%$ \\
\hline Parkinson's disease $(\mathrm{n}=1)$ & $0.8 \%$ \\
\hline Raynaud's syndrome $(\mathrm{n}=2)$ & $1.5 \%$ \\
\hline Metabolic cardiomyopathy $(\mathrm{n}=2)$ & $1.5 \%$ \\
\hline Flu $(\mathrm{n}=2)$ & $1.5 \%$ \\
\hline Exacerbation of erysipelas $(\mathrm{n}=1)$ & $0.8 \%$ \\
\hline Gout $(\mathrm{n}=2)$ & $1.5 \%$ \\
\hline Diseases of the musculoskeletal system $(\mathrm{n}=5)$ & $3.8 \%$ \\
\hline
\end{tabular}

patients. A positive result was in 50 (37.6\%) patients, negative - in $83(62.4 \%)$. In turn, rapid testing to determine the presence of the virus was not performed in $44(33.1 \%)$ cases, a positive result was - in 27 (20.3\%), a negative result - in $62(46.6 \%)$ patients. Enzyme-linked immunosorbent assay for antibodies to Sars-Cov-2 virus was not performed in $20(15.0 \%)$ patients, positive test result was - in 97 (72.9\%), negative result - in $16(12.0 \%)$ patients.

Chest computed tomography (CT) was performed on $69(51.9 \%)$ patients. According to CT OTC - unilateral lesions of the lung parenchyma were - in $4(9.0 \%)$, bilateral - in $61(81.0 \%)$ and 2 patients showed changes in the type of bronchitis.

The diagnosis of COVID infection was established: according to the combination of a specific clinical picture and a positive polymerase chain reaction for the presence of Sars-Cov-2 virus was in $50(37.6 \%)$ patients; increase in IgM titers to Sars-Cov-2 virus in $75(56.4 \%)$ patients; 6 (4.5\%) patients tested positive for the virus; in the presence of specific changes in the lung parenchyma according to CT - in $2(1.5 \%)$ patients.

Analysis of patients' temperature showed that normal 
body temperature was in $6(4.5 \%)$, subfebrile - $59(44.4 \%)$, moderately high - $56(42.1 \%)$, high - $11(8.3 \%)$, hyperpyretic - $1(0.8 \%)$ patient. The vast majority of patients had fever of moderately high and high levels $(p=0.001)$.

The most common comorbidities in the examined patients (Table 1) were Hypertension, IHD, CHF, obesity and DM. Hypertension was diagnosed in $90(67.7 \%)$ individuals, including 45 (50.0\%) women and 45 (50.0\%) men $\left(x^{2}=0.142, p=0.7\right)$. Analyzing the severity of Hypertension, it was found that $7(5.3 \%)$ patients had stage $1,72(54.1 \%)$ had stage 2, $15(11.3 \%)$ had stage 3 , and 8 $(6 \%)$ - 1 degree, in 74 (55.6\%) - 2 degree, in 12 (9\%) - 3 degree Hypertension, respectively. The course of Hypertension in $32(24.1 \%)$ patients was uncontrolled, in $101(75.9 \%)$ - controlled, respectively $\left(x^{2}=5.14, p=0.02\right)$. In turn, the uncontrolled course of Hypertension was observed in $14(10.5 \%)$ women and 18 (13.5\%) men, respectively $\left(x^{2}=0.918, p=0.338\right)$. The risk of cardiovascular complications in $4(3.0 \%)$ - low, $33(24.8 \%)$ - moderate, in $50(37.6 \%)$ - high and in $46(34.6 \%)$ patients - very high.

Among this array of patients, $91(68.4 \%)$ patients had IHD, namely angina pectoris - 7 (5.3\%), postinfarction cardiosclerosis - $8(6.0 \%)$, diffuse cardiosclerosis - 76 (57.1\%) patients, respectively. Also, a significant proportion - $79(59.4 \%)$ patients had a combination of Hypertension and IHD.

In turn, $113(85.0 \%)$ patients had signs of CHF, among them - stage I CHF was observed in 65 (48.9\%), stage IIA in $45(33.8 \%)$, stage IIB - in $3(2.3 \%)$ patients, respectively.

Obesity affected $47(35.3 \%)$ patients, including 26 $(19.5 \%)$ - stage 1, $11(8.3 \%)$ - stage 2, $12(9.0 \%)$ - stage 3 obesity, respectively. $32(24.1 \%)$ patients had T2D.

Among the acute complications that occurred during the stay of patients in hospital: acute myocardial infarction - in $2(1.5 \%)$, acute cerebrovascular accident (ACA) - in 3 $(2.3 \%)$, acute myocarditis - in $1(0.8) \%)$, acute thrombophlebitis - in $15(11.3 \%)$, acute heart failure - in 4 $(3.0 \%)$, verified pulmonary embolism - in $3(2.3 \%)$, sepsis/ infectious-toxic shock - in $1(0.8 \%)$ patient, respectively.

Statistical processing of the obtained data was performed on a personal computer using the statistical software package SPSS 12.0 for Windows. Quantitative data (with a normal distribution of characteristics) are presented in the form $(M \pm \sigma)$, where $M$ is the average value of the sample, and $\sigma$ is the standard deviation. The reliability of the difference in quantitative values was calculated by Student's criterion, the percentage $-X^{2}[25]$.

\section{Results}

Assessment of the severity of COVID infection according to OTC CT (Fig. 1) showed that the absence of specific changes (CT - 0) in the lungs was $2(2.9 \%)$, slight changes according to the type of "frosted glass" with a lesion $<25 \%$ lung parenchyma (CT-1) (average $17.00 \pm 4.47 \%$ ) - in 5 (7.3\%), moderate changes (CT-2) with a lesion of $25-50 \%$ (average $37.56 \pm 7.48 \%$ ) - in $16(23.2 \%$ ) patients, severe changes (CT-3) with a lesion of $50-75 \%$ (average $62.40 \pm 8.08 \%)$ - in $25(36.2 \%)$, critically severe impressions (CT-4) involving $>75 \%$ (average $87.62 \pm 10.56$ ) - in 21 $(30.4 \%)$ patients, respectively. This indicated a predominance of patients with moderate, severe and critically severe lung parenchyma $(23.2 \%, 36.2 \%$ and $30.4 \%$ vs. $2.9 \%$ and $7.3 \%, p=0.001$ ).

Also, according to the CO-RADS classification, which is standardized for patients with suspected COVID-19, the typical changes for CO-RADS 3 (medium risk of COVID) were in $1(1.5 \%)$ patient, CO-RADS 4 (high risk COVID) - in $10(14.5 \%)$ patients, CO-RADS 5 (very high risk of COVID) - in $58(84.0 \%)$ patients. Thus, most of the examined subjects had diffuse areas of turbidity of the "frosted glass" type and compaction of the lung parenchyma (CO-RADS 5) $(84.0 \%$ vs. $14.5 \%$ and $1.5 \%, p=0.001)$.

The vast majority of patients had bilateral lung damage ( $97 \%$ vs. $3 \%, p=0.0001$ ). Pulmonary insufficiency (Fig. 2) of the first degree was in $10(7.5 \%)$, second degree - in 41 $(30.8 \%)$, third degree - in $82(61.7 \%)$ patients, respectively. Acute respiratory distress syndrome was found in $6(4.5 \%)$ cases. Analysis of the severity of pulmonary insufficiency showed that the vast majority of patients had severe pulmonary insufficiency $(61.7 \%$ vs. $30.8 \%$ and $7.5 \%, p=0.001)$.

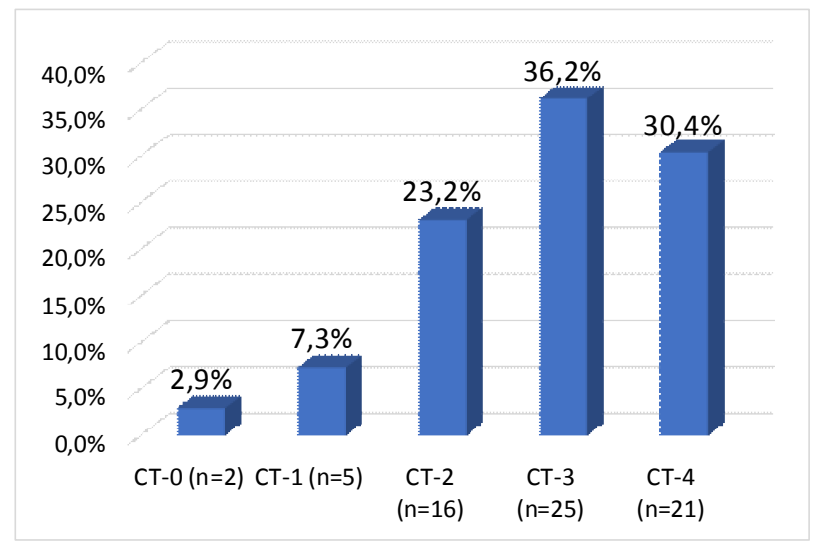

Fig. 1. Comparative graphs of the severity of lung parenchymal lesions according to chest computed tomography (CT).

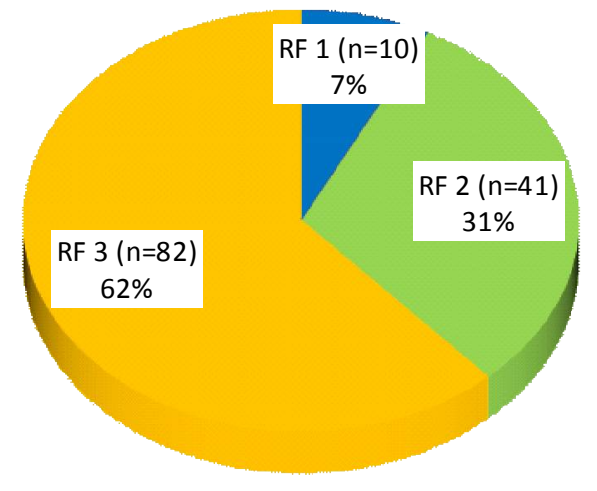

Fig. 2. The proportion of severity of respiratory failure (RF) in the patients with severe COVID-19 infection. 
Oxygen therapy using a face mask or nasal cannula was received by $76(57.1 \%)$ patients, by non-invasive CPAP therapy $56(42.1 \%)$ patients. No patient was switched to invasive oxygen support and 1 patient did not need oxygen support.

Analyzing laboratory parameters, it was found that anemia was present in $44(33.1 \%)$ patients. In turn, a decrease in glomerular filtration rate (GFR) less than 60 $\mathrm{ml} / \mathrm{min} / 1.72 \mathrm{~m}^{2}$ - in $82(61.7 \%)$ patients $(61.7 \%$ vs. $37.6 \%$, $\mathrm{p}=0.005)$. GFR ranged from 9 to $114 \mathrm{ml} / \mathrm{min} / 1.72 \mathrm{~m}^{2}$ (according to the formula CKD-EPI) and averaged $54.11 \pm 21.54 \mathrm{ml} / \mathrm{min} / 1.72 \mathrm{~m}^{2}$.

The level of C-reactive protein $(n=71)$, procalcitonin $(n=65)$, interleukin - $6(n=68)$, D-dimer $(n=57)$ in patients with severe COVID during the period of stay in the intensive care unit was also analyzed. therapy.

According to the methods of variation statistics, it was obtained that the minimum and maximum levels of $\mathrm{C}$ reactive protein were -8.030 and $406.2 \mathrm{mg} / \mathrm{l}$, respectively. The average value of the indicator is $135.8 \pm 86.4 \mathrm{mg} / \mathrm{l}$, the median is $124.0 \mathrm{mg} / \mathrm{l}$. Thus, the relatively low level (RLL) of C-reactive protein for this sample was defined as a value less than 25 percentile $(<68 \mathrm{mg} / \mathrm{l})-18(13.5 \%)$, the intermediate level of C-reactive protein as a value between 25 and 75 percentile (from 69 to $182 \mathrm{mg} / \mathrm{l}$ ) - 35 (26.3\%) and relatively high level (RHL) of C-reactive protein - > 75 percentile, respectively (>183 mg/l) - 18 (13.5\%) patients, respectively.

The minimum and maximum levels of procalcitonin were 0.01 and $7.57 \mathrm{ng} / \mathrm{ml}$, respectively. The average value of the indicator is $0.429 \pm 1.044 \mathrm{ng} / \mathrm{ml}$, the median is 0.13 $\mathrm{ng} / \mathrm{ml}$. Thus, the RLL of procalcitonin for this sample was defined as a value less than 25 percentile $(<0.07 \mathrm{ng} / \mathrm{ml})$ $20(15.0 \%)$, the intermediate level of procalcitonin as a

Table 2. Comparative data of patients' sex and age with severe COVID infection.

\begin{tabular}{|c|c|c|c|c|}
\hline Parameters & $\operatorname{Men}(n=65)$ & Women $(n=68)$ & Total $(n=133)$ & $\mathrm{p}$ value men/women \\
\hline Age & $60.55 \pm 13.38$ & $62.18 \pm 12.6$ & $61.38 \pm 12.96$ & 0.47 \\
\hline Term of hospitalization & $18.86 \pm 7.14$ & $18.94 \pm 10.75$ & $18.90 \pm 9.12$ & 0.96 \\
\hline The period of stay in intensive care & $7.800 \pm 5.133$ & $8.820 \pm 8.284$ & $8.320 \pm 6.919$ & 0.4 \\
\hline Hypertension & $45(69.2 \%)$ & $45(66.2 \%)$ & $90(67.7 \%)$ & 0.7 \\
\hline IHD & $47(72.3 \%)$ & $44(64.7 \%)$ & $91(68.4 \%)$ & 0.34 \\
\hline Combination of Hypertension and IHD & $38(58.5 \%)$ & $41(60.3 \%)$ & $79(59.4 \%)$ & 0.83 \\
\hline$A C A$ & $5(7.7 \%)$ & $6(8.8 \%)$ & $11(8.3 \%)$ & 0.81 \\
\hline $\mathrm{CHF}$ & $53(81.5 \%)$ & $60(88.2 \%)$ & $113(85 \%)$ & 0.28 \\
\hline T2D & $15(23.1 \%)$ & $17(25 \%)$ & $32(24.1 \%)$ & 0.79 \\
\hline Hyperglycemia & $10(15.4 \%)$ & $19(27.9 \%)$ & $29(21.8 \%)$ & 0.08 \\
\hline Reduction of GFR $<60 \mathrm{ml} / \mathrm{min} / 1.73 \mathrm{~m}^{2}$ & $34(52.3 \%)$ & $48(70.5 \%)$ & $82(61.7 \%)$ & 0.02 \\
\hline Average GFR & $59.71 \pm 22.8$ & $48.75 \pm 18.93$ & $54.11 \pm 21.54$ & 0.003 \\
\hline Anemia & $20(30.8 \%)$ & $24(35.3 \%)$ & $44(33.1 \%)$ & 0.58 \\
\hline Obesity & $20(30.8 \%)$ & $27(39.7 \%)$ & $47(35.3 \%)$ & 0.28 \\
\hline Thyroid disease & $2(3.1 \%)$ & $7(10.3 \%)$ & $9(6.7 \%)$ & 0.09 \\
\hline COPD/Asthma & $5(7.7 \%)$ & $4(5.9 \%)$ & $9(6.7 \%)$ & 0.67 \\
\hline Cancer & $3(4.6 \%)$ & $5(7.4 \%)$ & $8(6 \%)$ & 0.5 \\
\hline Gastrointestinal diseases & $6(9.2 \%)$ & $11(16.2 \%)$ & $17(12.8 \%)$ & 0.23 \\
\hline CRP & $142.4 \pm 83.5$ & $127.7 \pm 90.5$ & $135.8 \pm 86.4$ & 0.48 \\
\hline Procalcitonin & $0.247 \pm 0.236$ & $0.629 \pm 1.478$ & $0.429 \pm 1.044$ & 0.14 \\
\hline Interleukin-6 & $207.9 \pm 694.4$ & $219.0 \pm 797.9$ & $212.8 \pm 736.1$ & 0.95 \\
\hline D-dimer & $0.975 \pm 1.479$ & $1.430 \pm 1.995$ & $1.207 \pm 1.760$ & 0.33 \\
\hline Increased fibrinogen $(n=112)$ & $46(82.1 \%)$ & $54(96.4 \%)$ & $100(89.2 \%)$ & 0.01 \\
\hline Na level & $139.5 \pm 5.2$ & $138.9 \pm 4.4$ & $139.2 \pm 4.8$ & 0.52 \\
\hline K level & $3.968 \pm 0.912$ & $4.122 \pm 0.905$ & $4.045 \pm 0.907$ & 0.39 \\
\hline The degree of severity according to CT & $2.920 \pm 0.996$ & $2.760 \pm 1.091$ & $2.840 \pm 1.038$ & 0.53 \\
\hline Accumulation of fluid in the pleural cavity & $10(15.4 \%)$ & $4(5.9 \%)$ & $14(10.5 \%)$ & 0.07 \\
\hline
\end{tabular}

Notes: the reliability of the difference in quantitative values is calculated by Student's criterion. percent - according to criterion $X^{2}$. 


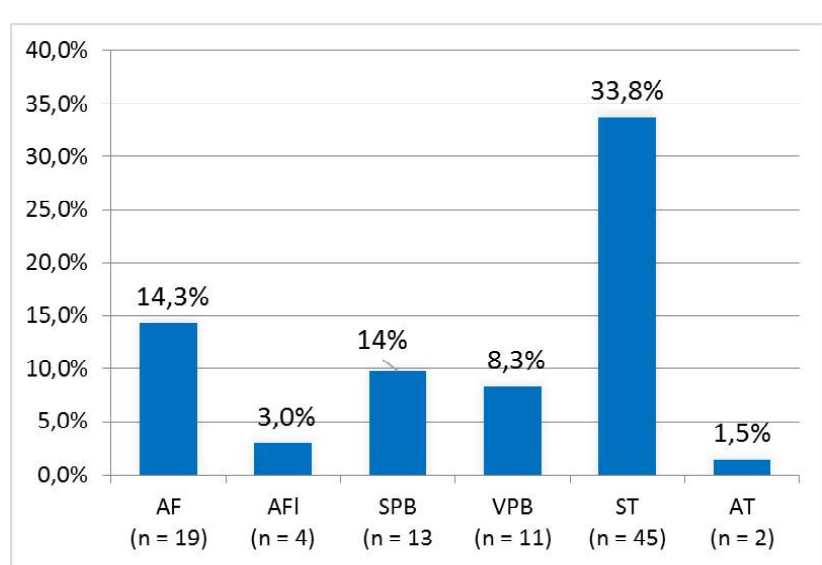

Fig. 3. Comparative data of the proportion of the patients with tachyarrhythmias at severe COVID-19 infection. AF - atrial fibrillation, AFI - atrial flutter, SPB - supraventricular premature beats, VPB - ventricular premature beats, ST - sinus tachycardia, AT - atrial tachycardia.

value between 25 and 75 percentile (from 0.08 to $0.34 \mathrm{ng} /$ $\mathrm{ml})-27(20.3 \%)$ patients and RHL of procalcitonin - > 75 percentile, respectively $(>0.35 \mathrm{ng} / \mathrm{ml})-18(13.5 \%)$ patients, respectively.

In turn, the minimum and maximum levels of interleukin6 are 2.95 and $4425 \mathrm{pg} / \mathrm{ml}$, respectively. The average value of the indicator is $212.8 \pm 736.1 \mathrm{pg} / \mathrm{ml}$, the median is 54.22 $\mathrm{pg} / \mathrm{ml}$. Thus, the RLL of interleukin- 6 for this sample was defined as a value less than 25 percentile $(<23 \mathrm{pg} / \mathrm{ml})-18$ $(13.5 \%)$, the intermediate level as a value between 25 and 75 percentile (from 24 to $109 \mathrm{pg} / \mathrm{ml}$ ) - $33(24.8 \%)$ and $\mathrm{RHL}$ - > 75 percentile, respectively $(>110 \mathrm{pg} / \mathrm{ml})-17(12.8 \%)$ patients, respectively.

The minimum and maximum levels of D-dimer were 0.14 and $8.31 \mu \mathrm{g}$, respectively. The mean value was $1.210 \pm 1.760 \mu \mathrm{g}$, and the median was $0.54 \mu \mathrm{g}$. Thus, the RLL of the D-dimer was defined as a value less than 25 percentile $(<0.3 \mu \mathrm{g})-18(13.5 \%)$, the intermediate level as a value between 25 and 75 percentile $(0.4$ to $1.0 \mu \mathrm{g})-20$ $(15.0 \%)$ and $\mathrm{RHL}->75$ percentile, respectively $(>1.1 \mu \mathrm{g})$ $19(14.3 \%)$ patients, respectively.

Analyzing the sex and age characteristics of the examined patients with severe COVID infection (Table 2) it was found that men and women did not differ in average age, length of hospitalization and period of stay in the intensive care unit, the structure of comorbid pathology, the results of most additional methods. However, there was a tendency that the proportion of patients with thyroid disease (10.3\% vs. $3.1 \%, p=0.09$ ) and hyperglycemia among women was higher $(27.9 \%$ vs. $15.4 \%, p=0.08)$. Also, females had a lower average level of glomerular filtration rate ( 48.75 vs. $59.71, p=0.003)$ and the proportion of patients with GFR $<60 \mathrm{ml} / \mathrm{min} / 1.73 \mathrm{~m}^{2}$ was significantly higher compared to men $(70.5 \%$ against $52.3 \%, p=0.02)$. Among the male, according to CT/radiography OTC there was a tendency to the predominance of fluid accumulation in the pleural cavity $(15.4 \%$ vs. $5.9 \%, p=0.07)$.
The frequency and structure of cardiac arrhythmias among patients with severe COVID infection were also analyzed according to a standard 12-lead electrocardiogram.

During the period of inpatient treatment in the vast majority of $86(64.7 \%)$ patients observed the presence of arrhythmias $(64.7 \%$ vs. $34.6 \%, p=0.001)$. Among them, 42 $(64.6 \%)$ men and $44(64.7 \%)$ women, $p=0.58$. In turn, the average length of stay in the intensive care unit in patients with arrhythmias (9.43 vs. 6.3 days, $p=0.02$ ) and the total length of hospitalization ( 20.22 vs. $16.49, p=0.01$ ) were significantly longer compared to the group of individuals without arrhythmias. It should be noted that the prevalence of arrhythmias did not depend on the severity of lung lesions according to CT OTC, the severity of pulmonary insufficiency and the clinical group of community-acquired pneumonia among patients with severe COVID-19.

$68(51.1 \%)$ patients with tachyarrhythmia took the leading position in the structure of disorders (Fig. 3). Among them, a number of patients had a combination of different heart rhythm disorders. Thus, AF was observed in $19(14.3 \%)$ patients, namely in $7(5.3 \%)$ paroxysmal, in 3 $(2.3 \%)$ - persistent and in $9(6.8 \%)$ patients - permanent form AF, respectively (Table 3). Among patients with acute AF paroxysms, $6(60.0 \%)$ patients underwent drug cardioversion and $4(40.0 \%)$ patients had spontaneous recovery of sinus rhythm within the first 48 hours after the onset of arrhythmia paroxysm. The CHA2DS2VASc score ranged from 2 to 5 and averaged $3.26 \pm 0.99$, indicating that all $A F$ patients had a high risk of thromboembolic complications.

In turn, Atrial fibrillation was registered in 4 (3.0\%), Atrial tachycardia in $2(1.5 \%)$, sinus tachycardia (ST) in $45(33.8 \%)$ patients. Frequent supraventricular arrhythmias - in 13 $(9.8 \%)$, ventricular arrhythmias (VA) - in $11(8.3 \%)$, among them - 1st grade according to Lown - in 7 (5.3\%), 2nd grade - in $3(2.3 \%), 4 \mathrm{~b}$ grade - in $1(0.8 \%)$ patient.

After analyzing the sex and age characteristics of patients (Table 4) with tachyarrhythmias, it was found that the average age of patients with and without tachyarrhythmias did not differ (61.35 vs. $61.42, p=0.97)$. In turn, there was no significant sex difference in the structure of arrhythmias, however, among women there was a tendency to a predominance of sinus tachycardia $(41.2 \%$ vs. $26.2 \%, p=0.06)$.

Patients in whom, according to the ECG, different types of bradyarrhythmias were recorded $60(45.1 \%)$, in some cases had a combination of different conduction disorders.

Table 3. Distribution of patients by forms of atrial fibrillation.

\begin{tabular}{|c|c|}
\hline AF characteristics & Proportion of patients $(n=19)$ \\
\hline \multicolumn{2}{|c|}{ Forms of $A F$} \\
\hline Paroxysmal $(n=7)$ & $5.3 \%$ \\
\hline Persistent $(n=3)$ & $2.3 \%$ \\
\hline Constant $(n=9)$ & $6.8 \%$ \\
\hline
\end{tabular}


Table 4. Sex and age features of tachyarrhythmia's structure in patients with severe COVID infection.

\begin{tabular}{|l|c|c|c|}
\hline \multicolumn{1}{|c|}{ Rhythm disorders } & Men $(\mathrm{n}=65)$ & Women $(\mathrm{n}=68)$ & $\mathrm{p}$ value \\
\hline $\begin{array}{l}\text { Tachyarrhythmias total } \\
(\mathrm{n}=68)\end{array}$ & $33(50.8 \%)$ & $35(51.5 \%)$ & $=0.93$ \\
\hline AF $(\mathrm{n}=19)$ & $10(15.4 \%)$ & $9(13.2 \%)$ & $=0.72$ \\
\hline Sinus tachycardia $(\mathrm{n}=45)$ & $17(26.2 \%)$ & $28(41.2 \%)$ & $=0.06$ \\
\hline Atrial fibrillation $(\mathrm{n}=4)$ & $3(4.6 \%)$ & $1(1.5 \%)$ & $=0.28$ \\
\hline Atrial tachycardia $(\mathrm{n}=2)$ & $2(3.1 \%)$ & $0(0 \%)$ & $=0.14$ \\
\hline $\begin{array}{l}\text { Supraventricular arrhythmia } \\
\text { (n=13) }\end{array}$ & $7(10.8 \%)$ & $6(8.8 \%)$ & $=0.7$ \\
\hline Ventricular arrhythmia $(\mathrm{n}=11)$ & $7(10.8 \%)$ & $4(5.9 \%)$ & $=0.3$ \\
\hline
\end{tabular}

Notes: the reliability of the percentage difference is calculated according to criterion $x^{2}$.

Table 5. Sex and age features of bradyarrhythmias structure in patients with severe COVID infection.

\begin{tabular}{|l|c|c|c|}
\hline \multicolumn{1}{|c|}{ Rhythm disorders } & Men $(\mathrm{n}=65)$ & Women $(\mathrm{n}=68)$ & $\mathrm{p}$ value \\
\hline $\begin{array}{l}\text { Bradyarrhythmias total } \\
(\mathrm{n}=60)\end{array}$ & $32(49.2 \%)$ & $28(41.2 \%)$ & $=0.35$ \\
\hline Sinus bradycardia $(\mathrm{n}=16)$ & $9(13.8 \%)$ & $7(10.3 \%)$ & $=0.52$ \\
\hline LBBB $(\mathrm{n}=3)$ & $3(4.6 \%)$ & $0(0 \%)$ & $=0.07$ \\
\hline LAFB $(\mathrm{n}=11)$ & $5(7.7 \%)$ & $6(8.8 \%)$ & $=0.81$ \\
\hline LPFB $(\mathrm{n}=4)$ & $1(1.5 \%)$ & $3(4.4 \%)$ & $=0.33$ \\
\hline RBBB $(\mathrm{n}=30)$ & $17(26.2 \%)$ & $13(19.1 \%)$ & $=0.33$ \\
\hline $\begin{array}{l}\text { First-degree AV block } \\
(\mathrm{n}=14)\end{array}$ & $7(10.8 \%)$ & $7(10.3 \%)$ & $=0.92$ \\
\hline $\begin{array}{l}\text { Second-degree AV block } \\
(\mathrm{n}=1)\end{array}$ & $1(1.5 \%)$ & $0(0 \%)$ & $=0.3$ \\
\hline
\end{tabular}

Notes: the reliability of the percentage difference is calculated according to criterion $x^{2}$.

Table 6. Sex and age features of ischemic changes structure and repolarization disorders in patients with severe COVID infection.

\begin{tabular}{|l|c|c|c|}
\hline \multicolumn{1}{|c|}{ Rhythm disorders } & Men $(\mathrm{n}=65)$ & Women $(\mathrm{n}=68)$ & $\mathrm{p}$ value \\
\hline Negative T $(\mathrm{n}=91)$ & $44(67.7 \%)$ & $47(69.1 \%)$ & $=0.86$ \\
\hline Early repolarization $(\mathrm{n}=14)$ & $5(7.7 \%)$ & $9(13.2 \%)$ & $=0.29$ \\
\hline $\begin{array}{l}\text { Elevation of the ST segment } \\
(\mathrm{n}=6)\end{array}$ & $3(4.6 \%)$ & $3(4.4 \%)$ & $=0.95$ \\
\hline $\begin{array}{l}\text { Depression of the } \\
\text { ST segment }(\mathrm{n}=54)\end{array}$ & $25(38.5 \%)$ & $29(42.6 \%)$ & $=0.62$ \\
\hline Pathological Q wave $(\mathrm{n}=9)$ & $5(7.7 \%)$ & $4(5.9 \%)$ & $=0.67$ \\
\hline LV overload $(\mathrm{n}=27)$ & $13(20.0 \%)$ & $14(20.5 \%)$ & $=0.93$ \\
\hline LV hypertrophy $(\mathrm{n}=45)$ & $27(41.5 \%)$ & $18(26.5 \%)$ & $=0.06$ \\
\hline RV overload $(\mathrm{n}=8)$ & $5(7.7 \%)$ & $3(4.4 \%)$ & $=0.42$ \\
\hline RV hypertrophy $(\mathrm{n}=12)$ & $9(13.8 \%)$ & $3(4.4 \%)$ & $=0.05$ \\
\hline SIQIIITIII sign & $5(7.7 \%)$ & $2(2.9 \%)$ & $=0.22$ \\
\hline QT prolongation & $1(1.5 \%)$ & $5(7.35 \%)$ & $=0.1$ \\
\hline P-pulmonale $(\mathrm{n}=6)$ & $3(4.6 \%)$ & $3(4.4 \%)$ & $=0.95$ \\
\hline P-mitrale $(\mathrm{n}=7)$ & $4(6.2 \%)$ & $3(4.4 \%)$ & $=0.65$ \\
\hline Delta wave $(\mathrm{n}=1)$ & $0(0 \%)$ & $1(1.5 \%)$ & $=0.32$ \\
\hline
\end{tabular}

Notes: the reliability of the percentage difference is calculated according to criterion $x^{2}$.
Among the blockades were registered: sinus bradycardia in $16(12.0 \%)$, left bundle branch block (LBBB) - in $3(2.3 \%)$, left anterior fascicular block (LAFB) - in 11 (8.3\%), left posterior fascicular block (LPFB) - in $4(3.0 \%)$, right bundle branch block (RBBB) - in 30 (22.6\%), First-degree AV block - in $14(10.5 \%)$, Second- degree AV block - in $1(0.8 \%)$ patient, respectively.

Analyzing the sex and age characteristics of patients with conduction disorders (Table 5), it was found that the average age of patients with blockade was higher compared with patients without bradyarrhythmias (64.05 vs. $59.19, p=0.03)$. In the structure of bradyarrhythmias among men there was a tendency to predominance of LBBB, compared with women $(4.6 \%$ vs. $0 \%, p=0.07)$.

The results of the ECG analysis showed that the majority of patients (119 people, which was $89.5 \%$ ) - had various ischemic changes and/or disorders of myocardial repolarization. Thus, inversion of the $\mathrm{T}$ wave was registered in $91(68.4 \%)$, signs of early ventricular repolarization in 14 $(10.5 \%)$, elevation of the ST segment in $6(4.5 \%)$, depression of the ST segment in 54 (40.6\%), pathological Q wave - in $9(6.8 \%)$. In turn, the signs of left ventricular overload were determined - in $27(20.3 \%)$, right ventricle in $8(6.0 \%)$, the sign of SIQIIITIII - in $7(5.3 \%)$, QT prolongation - in $6(4.5 \%)$ of patients. Also signs of left ventricular hypertrophy - $45(33.8 \%)$, signs of right ventricular hypertrophy - in $12(9.0 \%)$, the presence of p-pulmonale - 6 (4.5\%), p-mitrale - $7(5.3 \%)$ patients, respectively.

Analyzing the sex and age characteristics of patients with ischemic changes/repolarization disorders (Table 6), it was found that the average age of patients with ischemic changes on the ECG was significantly higher compared to patients without signs of repolarization disorders (62.13 vs. 55.0, $p=0.05$ ). In the structure of signs of repolarization disorders among men there was a predominance of right ventricular hypertrophy $(13.8 \%$ vs. $4.4 \%, p=0.05)$ and a tendency to predominance of left ventricular hypertrophy $(41.5 \%$ vs. $26.5 \%, p=0.06)$.

\section{Discussion}

Our study found that the most common comorbidities in patients with severe COVID-19 were Hypertension $67.7 \%$, IHD $-68.4 \%$, CHF $-48.9 \%$, obesity $-35.3 \%$ and diabetes - in $24.1 \%$ of patients, respectively. Our data are in some way consistent with the results of studies by other scientists, which analyzed the structure of comorbid pathology among individuals with severe COVID-19.

Thus, among the 5,700 patients with COVID-19 who were hospitalized in $12 \mathrm{New}$ York hospitals between March 1 and April 4, 2020, the most common comorbidities were Hypertension $(56.6 \%)$, obesity $(41.7 \%)$, and diabetes $(33.8 \%)$. In turn, $30.7 \%$ of patients had fever, $17.3 \%$ had a respiratory rate of more than 24 breaths/min, and $27.8 \%$ required oxygen therapy [26]. In a meta-analysis of 25 studies (4881 patients) related to the study of COVID-19 found that the most common comorbidity among patients 
with severe disease was Hypertension (33.4\%), in second place - diabetes (14.4\%) [ 31].

We found that the prevalence of cardiac arrhythmias in patients with severe COVID-19 is $67.7 \%$. Some literature sources also describe data on the analysis of the prevalence and structure of arrhythmias in patients with severe COVID-19. Thus, in a report by Chinese scientists Wang D. et al. (2020) cardiac arrhythmias were reported in $44.4 \%$ of patients in the COVID-19 intensive care unit [29]. A meta-analysis of 5 studies (1553 patients) with COVID19 was also performed. Among 349 (22.47\%) patients with severe disease, in 105 (30.09\%) developed various arrhythmias [32].

In the course of our study it was found that among all arrhythmias, tachyarrhythmias predominate $-51.1 \%$, in the structure of which the most common sinus tachycardia $48 \%$ and $\mathrm{AF}-14.3 \%$ of patients, respectively. In turn, sinus tachycardia was significantly more common among women. The prevalence of bradyarrhythmias was $45.1 \%$, the structure of which was dominated by sinus bradycardia - in $12 \%$ and RBBB - in $22.6 \%$. Among men, there was a tendency for LBBB to predominate.

According to the available literature, among patients with COVID-19 AF was detected in $19-21 \%$ of all cases [13, 17]. One study reported the prevalence of AF in $36 \%$ of patients with cardiovascular disease, with AF observed in $42 \%$ of patients who did not survive [17]. In a small report, up to $75 \%$ of hospitalized geriatric patients with COVID-19 had a history of AF in the past [12]. The latest statistics from the COVID-19 working group of the Italian National Institutes of Health showed that $24.5 \%$ of the 355 patients who died of COVID-19 (mean age 79.5 years, $70 \%$ of men) had a history of AF before infection with SARS-CoV-2 [23]. Reliable data on the first-onset AF in patients with COVID-19 are limited. Based on reports of clinical cases and small studies, the prevalence of the first AF paroxysm ranges from $3.6 \%$ to $6.7 \%$ in patients with COVID-19 [3, 7, 8, 28]. Both sinus tachycardia and AF are independent predictors of disease severity, myocardial injury, and poor outcomes in COVID-19 [30].

Also, in a single-center US study of 700 patients with COVID-19 (11\% of whom were in the intensive care unit), AF was observed in 25 patients, significant bradyarrhythmias in 9 patients, and unstable VT in 10 patients, however, no patient had persistent monomorphic ventricular tachycardia, ventricular fibrillation, or complete heart block [7].

In a study by D. Kir et al (2020), a patient with COVID-19 infection who had unchanged echocardiography and cardiac biomarkers developed bradycardia and intermittent high-grade atrioventricular block [19]. G. Peigh and coauthors (2020) reported sinus node dysfunction in two cases of COVID-19. Sinus bradycardia with subsequent episodes of accelerated idioventricular rhythm was observed in these patients [24]. In a clinical case, a patient with COVID-19 is described who suffered from grade 1 atrioventricular block but during hospitalization the rhythm switched to grade 2 atrioventricular block type Mobitz-1 followed by the development of complete atrioventricular block [16]. In other cases, elderly patients with multiple cardiac risk factors who have high-grade atrioventricular block and/or intraventricular conduction block are described $[2,18]$.

Transient sinus bradycardia is a possible manifestation of COVID-19 and is important for close monitoring. The etiology can be multifactorial, namely hypoxia, inflammatory cardiomyocyte damage, and drug response may be triggers for sinus bradycardia. High levels of pro-inflammatory cytokines can directly affect the sinoatrial node, contributing to the development of bradycardia. This may be a harbinger of the onset of a serious cytokine storm. In turn, sinus bradycardia, nodal rhythm, idioventricular rhythm occurred immediately before cardiac arrest - therefore, the development of bradyarrhythmias in a patient with severe COVID-19 is a marker of the risk of approaching cardiovascular collapse [1].

Of undoubted scientific interest was a fragment of the study devoted to the study of the prevalence of ischemic changes and/or repolarization disorders. Such changes on the electrocardiogram were found in $89.5 \%$ of patients, the structure of repolarization disorders was dominated by the presence of inversion of the $\mathrm{T}$ wave $(68.4 \%)$ and depression of the ST segment $(40.6 \%)$. In turn, the mean age of patients with ischemic changes on the electrocardiogram was significantly higher compared to patients without signs of repolarization disorders. Among men, there was a predominance of right ventricular hypertrophy and a tendency to predominate left ventricular hypertrophy.

It is known that COVID-19 infection, associated with myocardial damage, can cause ST segment deviation (elevation or depression), inversion of the $\mathrm{T}$ wave and the appearance of pathological $Q$ wave $[11,15]$. One study found that ST-segment and T-wave changes were the most common abnormalities in patients requiring hospitalization in the intensive care unit and occurred in $40 \%$ of patients [21]. Another study noted that nonspecific repolarization changes, including ST-segment and T-wave abnormalities, were found in $41 \%$ of patients. These changes have been reported as a result of myocardial damage and are associated with poor prognosis, including an increased need for hospitalization, more frequent mechanical ventilation support, and increased mortality [6, 30]. Another study involved 219 patients hospitalized through COVID19 from April 15 to May 5, 2020. Patients were divided into two groups according to the severity of COVID-19 infection: severe $(n=95)$ and mild $(n=124)$. ST-segment depression ( $28 \%$ vs. $14 \%)$, T-wave inversion ( $29 \%$ vs. $16 \%)$, ST-T changes $(36 \%$ vs. $21 \%)$, and the presence of fragmented QRS (fQRS) ( $17 \%$ vs. $7 \%$ ) were more common. in the group with severe disease, compared with patients with mild COVID-19 [5]. 
Thus, the literature data, in some way, confirm the results obtained in our study. In general, it can be concluded that COVID-19 infection adversely affects the cardiovascular system and leads to changes in the ECG, which may be due to cytokine storm, hypoxia, changes in electrolytes, coronary spasm, microthrombi, and direct endothelial or myocardial damage.

Knowledge of the features of arrhythmias and typical changes in the ECG in the future can help physicians in the assessment and treatment of patients with COVID-19. It should be noted that changes in the electrocardiogram to predict heart damage in COVID-19 require further study.

\section{Conclusions}

1. It was found that the most common comorbid pathologies in patients with severe COVID-19 were hypertension $(67.7 \%)$, coronary heart disease $(68.4 \%)$, chronic heart failure $(48.9 \%)$, obesity $(35.3 \%)$ and diabetes mellitus $(4.1 \%)$.

2. The study found that the prevalence of cardiac arrhythmias in patients with severe COVID-19 was $67.7 \%$.

\section{References}

[1] Amaratunga, E.A., Corwin, D.S., Moran, L., \& Snyder, R. (2020). Bradycardia in patients with COVID-19: a calm before the storm? Cereus, 12. doi: 10.7759/cureus.8599

[2] Angeli, F., Spanevello, A., De Ponti, R., Visca, D., Marazzato, J., \& Palmiotto, G. (2020). Electrocardiographic features of patients with COVID-19 pneumonia. Eur. J. Intern. Med., 78, 101-106. doi: 10.1016/j.ejim.2020.06.015

[3] Azarkish, M., Laleh Far, V., Eslami, M., \& Mollazadeh, R. (2020). Transient complete heart block in a patient with critical COVID19. Eur. Heart J., 41, 21-31. doi: 10.1093/eurheartj/ehaa307 [4] Babapoor-Farrokhran, S., Rasekhi, R. T., Gill, D., Babapoor, S., \& Amanullah, A. (2020). Arrhythmia in COVID-19. SN Compr. Clin. Med., 1-6. doi: 10.1007/s42399-020-00454-2

[5] Barman, H. A., Atici, A., Alici, G., Sit, O., Tugrul, S., Gungor, B. ... Sahin, I. (2020). The effect of the severity COVID-19 infection on electrocardiography. Am. J. Emerg. Med., S07356757(20)30889-5. doi: 10.1016/j.ajem.2020.10.005

[6] Bertini, M., Ferrari, R., \& Guardigli, G. (2020). Electrocardiographic features of 431 consecutive, critically ill COVID-19 patients: an insight into the mechanisms of cardiac involvement. Europace, 22(11), 1848-1854. doi: 10.1093/ europace/euaa258

[7] Bhatla, A., Mayer, M.M., Adusumalli, S., Hyman, M.C., Oh, E., Tierney, A. ... Deo, R. (2020). COVID-19 and cardiac arrhythmias. Heart Rhythm., 17(9), 1439-1444. doi: 10.1016/ j.hrthm.2020.06.016

[8] Chen, Q., Xu, L., Dai, Y., Ling, Y., Mao, J., \& Qian, J. (2020). Cardiovascular manifestations in severe and critical patients with COVID-19. Clin. Cardiol., 43(7): 796-802. doi: 10.1002/ clc. 23384

[9] Chorin, E., Wadhwani, L., Magnani, S., Dai, M., Shulman, E., Nadeau-Routhier, C. ... Jankelson, L. (2020). QT interval prolongation and torsade de pointes in patients with COVID19 treated with hydroxychloroquine/azithromycin. Heart Rhythm., 17(9), 1425-1433. doi: 10.1016/j.hrthm.2020.05.014

[10] Colon, C.M., Barrios, J.G., Chiles, J.W., McElwee, S.K., Russell, D.W., Maddox, W.R., \& Kay, G.N. (2020). Atrial Arrhythmias in COVID-19 patients. JACC Clin. Electrophysiol., 6(9), 11891190. doi: 10.1016/j.jacep.2020.05.015
3. Among all arrhythmias, tachyarrhythmias predominated $-51.1 \%$, in the structure of which sinus tachycardia $(48 \%)$ and atrial fibrillation $(14.3 \%)$ were most common. Significantly more often recorded sinus tachycardia among women.

4. The prevalence of bradyarrhythmias was $45.1 \%$, the structure of which was dominated by sinus bradycardia $(12 \%)$ and RBBB (22.6\%). Among men, there was a tendency to the predominance of LBBB.

5. The prevalence of ischemic changes and/or repolarization disorders according to ECG data was $89.5 \%$, the structure of which was dominated by the presence of inversion of the T wave $(68.4 \%)$ and depression of the ST segment $(40.6 \%)$. In turn, the mean age of patients with ischemic ECG changes was significantly higher compared to patients without signs of repolarization disorders. Among men, the predominance of right ventricular hypertrophy and the tendency to predominate left ventricular hypertrophy were observed.

[11] Elias, P., Poterucha, T.J., \& Jain, S.S. (2020). The prognostic value of electrocardiogram at presentation to emergency department in patients with COVID-19. Mayo Clin. Proc., 95(10), 2099-2109. doi: 10.1016/j.mayocp.2020.07.028

[12] Fumagalli, S., Salani, B., Gabbani, L., Mossello, E., \& Ungar, A. (2020). Covid-19 cases in a no-Covid-19 geriatric acute care setting. A sporadic occurrence? Eur. J. Intern. Med., 77, 141142. doi: $10.1016 /$ j.ejim.2020.04.058

[13] Gopinathannair, R., Merchant, F.M., Lakkireddy, D.R., Etheridge, S.P., Feigofsky, S., Han, J.K. ... Russo, A.M. (2020). COVID19 and cardiac arrhythmias: a global perspective on arrhythmia characteristics and management strategies. J. Interv. Card Electrophysiol., 59(2), 329-336. doi: 10.1007/s10840-02000789-9

[14] Guo, T., Fan, Y., Chen, M., Wu, X., Zhang, L., He, T. ... Lu, Z. (2020). Cardiovascular Implications of Fatal Outcomes of Patients With Coronavirus Disease 2019 (COVID-19). JAMA Cardiol., 5(7), 811-818. doi:10.1001/jamacardio.2020.1017

[15] Haseeb, S., Gul, E.E., \& Cinier, G. (2020). Value of electrocardiography in coronavirus disease 2019 (COVID19). J. Electrocardiol., 62, 39-45. doi: 10.1016/ j.jelectrocard.2020.08.007

[16] He, J., Wu, B., \& Chen, Y. (2020). Characteristic electrocardiographic manifestations in patients with COVID19. Can J. Cardiol. doi: 10.1016/j.cjca.2020.03.028

[17] Inciardi, R.M., Adamo, M., Lupi, L., Cani, D.S., Di Pasquale, M., \& Tomasoni, D. (2020). Characteristics and outcomes of patients hospitalized for COVID-19 and cardiac disease in Northern Italy. Eur. Heart J., 41(19), 1821-1829. https://doi.org/ 10.1093/eurheartj/ehaa388

[18] Jean-Louis, F., Adedayo, A., \& Ajibawo, T. (2020). A rare case of resolution of high-degree atrioventricular block associated with COVID-19. J. of Medical Cases, 11(8), 243-245. https:// doi.org/10.14740/jmc3524

[19] Kir, D., Mohan, C., \& Sancassani, R. (2020). Heart Brake: An Unusual Cardiac Manifestation of COVID-19. JACC Case Rep., 2(9), 1252-1255. doi: 10.1016/j.jaccas.2020.04.026

[20] Lakkireddy, D.R., Chung, M.K., Gopinathannair, R., Patton, K.K., Gluckman, T.J., Turagam, M. ... Russo, A.M. (2020). Guidance 
for cardiac electrophysiology during the COVID-19 pandemic from the Heart Rhythm Society COVID-19 Task Force; Electrophysiology Section of the American College of Cardiology; and the Electrocardiography and Arrhythmias Committee of the Council on Clinical Cardiology, American Heart Association. Heart Rhythm., 17(9), e233-e241. doi: 10.1016/j.hrthm.2020.03.028

[21] Li, Y., Liu, T., Tse, G., \& Wu, M. (2020). Electrocardiograhic characteristics in patients with coronavirus infection: a singlecenter observational study. Ann. Noninvasive Electrocardiol., 20. doi: 10.1111/anec.12805

[22] Liu, K., Fang, Y.-Y., Deng, Y., Liu, W., Wang, M.-F., Ma, J.-P. ... Liu, H.G. (2020). Clinical characteristics of novel coronavirus cases in tertiary hospitals in Hubei Province. Chin. Med. J., 133(9), 1025-1031. doi: 10.1097/CM9.0000000000000744

[23] Onder, G., Rezza, G., \& Brusaferro, S. (2020). Case-Fatality Rate and Characteristics of Patients Dying in Relation to COVID19 in Italy. JAMA, 323(18), 1775-1776. doi: 10.1001/ jama.2020.4683

[24] Peigh, G., Leya, M.V., Baman, J.R., Cantey, E.P., Knight, B.P., \& Flaherty, J. D. (2020). Novel coronavirus 19 (COVID-19) associated sinus node dysfunction: a case series. Eur. Heart J. Case Rep., 4(FI1), 1-6. https://doi.org/10.1093/ehjcr/ytaa132

[25] Rebrova, O.Yu. (2006). Статистический анализ медицинских данных. Применение пакета прикладных программ STATISTICA [Statistical analysis of medical data. Application of the STATISTICA application package]. M.: МедиаСфера - M.: MediaSfera.

[26] Richardson, S., Hirsch, J.S., Narasimhan, M., Crawford, J.M., McGinn, T., \& Davidson, K.W. (2020). Presenting
Characteristics, Comorbidities, and Outcomes Among 5700 Patients Hospitalized With COVID-19 in the New York City Area. JAMA., 323(20), 2052-2059. doi: 10.1001/ jama.2020.6775

[27] Russo, V., Rago, A., Carbone, A., Bottino, R., Ammendola, E., Della Cioppa, N. ... Nigro, G. (2020). Atrial Fibrillation in COVID19: From Epidemiological Association to Pharmacological Implications. J. Cardiovasc. Pharmacol., 76(2), 138-145. doi: 10.1097/FJC.0000000000000854

[28] Sala, S., Peretto, G., De Luca, G., Farina, N., Campochiaro, C., Tresoldi, M. ... Della Bella, P. (2020). Low prevalence of arrhythmias in clinically stable COVID-19 patients. Pacing Clin. Electrophysiol., 43(8), 891-893. doi: 10.1111/pace.13987

[29] Wang, D., Hu, B., Hu, C., Zhu, F., Liu, X., Zhang, J. ... Peng, Z. (2020). Clinical Characteristics of 138 Hospitalized Patients With 2019 Novel Coronavirus-Infected Pneumonia in Wuhan, China. JAMA, 323(11), 1061-1069. doi: 10.1001/ jama.2020.1585

[30] Wang, Y., Chen, L., \& Wang, J. (2020). Electrocardiogram analysis of patients with different types of COVID-19. Ann. Noninvasive Electrocardiol., 20 doi: 10.1111/anec.12806

[31] Wang, Z., Deng, H., Ou, C., Liang, J., Wang, Y., Jiang, M., \& Li, S. (2020). Clinical symptoms, comorbidities and complications in severe and non-severe patients with COVID-19, Medicine, 99(48), e23327 doi: 10.1097/MD.0000000000023327

[32] Wen, W., Zhang, H., Zhou, M., Cheng, Y., Ye, L., Chen, J., Wang, M., Feng, Z. (2020). Arrhythmia in patients with severe coronavirus disease (COVID-19): a meta-analysis. Eur. Rev. Med. Pharmacol. Sci., 24(21), 11395-11401. doi: 10.26355/ eurrev_202011_23632

\section{ГЕНДЕРНО-ВІКОВІ ОСОБЛИВОСТІ ПОШИРЕНОСТІ ТА СТРУКТУРИ ПОРУШЕНЬ СЕРЦЕВОГО РИТМУ У ПАЦІЄНТІВ 3 ТЯЖКИМ ПЕРЕБІГОМ COVID-IHФЕКЦІї \\ Мостовой Ю.М., Данілевич Т.Д.}

З'являється все більше доказів того, що аритмії є одним з основних ускладнень COVID-19 інфрекції. Запалення міокарда, цитокіновий иторм, гіпоксія, зміни рівня електролітів, спазм коронарних судин, мікротромби можуть бути фракторами, що сприяють появі порушень ритму та виникнення змін на електрокардіограмі. Метою роботи було встановити гендерновікові особливості поширеності та структури порушень серцевого ритму у пацієнтів з важким перебігом COVID-інфекції. У ході дослідження обстежено 133 пацієнтів з важким перебігом COVID-19 інфекції, які перебували у відділенні інтенсивної терапії міської клінічної лікарні №1 м. Вінниця у період з квітень - по грудень 2020 р. та у результаті лікування з покращенням самопочуття були виписані з лікарні. Статистичну обробку отриманих даних виконали за допомогою пакету статистичних програм SPSS 12.0 для Windows з використанням параметричних та непараметричних методів статистичного аналізу. Встановлено, що найчастішими коморбідними патологіями у пацієнтів з важким перебігом COVID-19 були - гіпертонічна хвороба (ГX) 90 (67,7\%), ішемічна хвороба серия (IXC) 91 (68,4\%), хронічна серцева недостатність (XCH) 65 (48,9\%), ожиріння 47 (35,3\%) та иукровий діабет (ЦД) 32 (24,1\%). Виявлено, що поширеність порушень серцевого ритму у пацієнтів з важким перебігом COVID-19 склала 86 (64,7\%). Серед усіх порушень ритму переважали тахіаритмії - 68 (51,1\%), у структурі яких найчастіше зустрічалася синусова тахікардія 45 (33,8\%) та фібриляція передсердь - 19 (14,3\%) пацієнтів, відповідно. У свою чергу, синусову тахікардію достовірно частіше реєстрували серед жінок. Поширеність брадіаритмій становила 60 $(45,1 \%)$ випадків, у структурі яких переважали синусова брадикардія 16 (12\%) та блокада правої ніжки пучка Гіса 30 (22,6\%). Серед чоловіків спостерігалася тенденція до переважання повної блокади лівої ніжки пучка Гіса. Поширеність ішемічних змін та/або порушень реполяризації за даними ЕКГ становила 119 (89,5\%), у структурі яких переважала наявність інверсіі зубия T 91 (68,4\%) та депресії сегменту ST у 54 (40,6\%) випадках. У свою чергу, середній вік пацієнтів з ішемічними змінами на ЕКГ був достовірно вищим, порівняно з пацієнтами без ознак порушень реполяризації. Серед чоловіків спостерігалася переважання гіпертрофії правого шлуночка та тенденція до переважання гіпертрофії лівого шлуночка.

Ключові слова: COVID, порушення серцевого ритму, аритмія, фрібриляція передсердь, екстрасистолія, блокади, гіпертонічна хвороба, ішемічна хвороба серця, хронічна серцева недостатність. 